\title{
A Comparison of the Leadership Behavior of Winning and Losing Basketball Coaches
}

\section{比較勝方與負方 \\ 中學籃球教練之領導行為}

Lam Tak -ching, Eddlie (Doctoral student) \& Dr. Zhang, James J (Assistant Professor) Department of Health and Human Performance, University of Houston,U.S.A. 林 德 正 (博士研究生) / 㖘 建 輝 博 士 (助理教授) 美國休斯頓大學

\section{摘 要}

從研究得悉, 球隊之比賽成績會影響敉練之領 導行為。不過, 大多數這類研究都在美國進行。然 不同之文化背景會對運動員之表現及教練之領導行 為產生一定之影響力。這份研究主要是比較香港勝 方與負方中學籃球敎練之領導行為。參與研究者共 有56名男性，全屬香港中學92-93年度學界男子甲組 籃球比賽之籃球教練。所用之問卷 “運動教練領導 行為量表” 共測試五類領導行為, 分別是：正面反 映、訓練及指導、交誼上的支持、民主行為、及專 制行為。研究結果發現勝方與負方之籃球敎練在領 導行為沒有明顯之差異。建議將來之研究須考慮不 同文化背景及其它因素。

\section{Objective}

Chelladurai (1985) indicated that leadership is the behavioral process of influencing subordinates toward organizational goals. In the sport setting, the coaches have great influence over the athletes toward the team goals. The Leadership Scale for Sports (LSS) is based on the multidimensional model of leadership that considers the coach's personality, the demands of each situation and the needs of the athletes. Using the LSS, this study attempts to investigate and distinguish those coaching behaviors that can influence the athletes in achieving the team goals. As a result, a better understanding of the coaching behaviors can benefit both the coaches and the athletes.

In Hong Kong, few, if any, studies have been conducted that relate to leadership behaviors. Thus, there is a need to study this phenomenon and attempt to better understand and improve coaching so that student athletes may benefit. This study is designed to compare the leadership behaviors of winning and losing high school basketball coaches in Hong Kong by utilizing the Leadership Scale for Sports (Chelladurai \& Saleh, 1980).

\section{Theoretical Framework}

The multidimensional model of leadership (Chelladurai \& Saleh, 1980) is a synthesis of various situational approaches to understanding leadership. These approaches include the characteristics of the leader, the needs and desires of the members, and the demands of the organization. The major thesis of the model is that performance and satisfaction are a function of the congruence among three states of leadership: actual leader behavior, leaders behavior preferred by members, and required leader behavior. According to the model, these three types of leader behaviors are affected by the antecedents of leader characteristics, member characteristics, and situational characteristics. The coach's self-perception version of the Leadership Scale for Sports (Chelladurai \& Saleh, 1980) was used to measure the coach's behavior. This version of the scale is based on a multidimensional model of leadership that considers the coach's behavioral characteristics.

The Leadership Scale for Sports (LSS) was introduced and developed by Chelladurai and Saleh (1980). The LSS is a 40-item scale consisting of five subscales of leader behaviors. The five leader behavior dimensions measured include 'Training and Instruction 
Behavior', 'Democratic Behavior', 'Autocratic Behavior', 'Social Support Behavior', and 'Positive Feedback Behavior'. Three versions of the LSS are available: (a) athlete's preference, (b) athlete's perception of coach's behavior, and (c) coach's own perception of behavior. Only the coach's self-perception version was used in this study. Item responses were based on a 5-point Likert scale: always (5), often (4), occasionally (3), seldom (2), and never (1). Five points were given to 'always', four points to 'often', three points to 'occasionally', two points to 'seldom', and one point for 'never'. The total scores for each category were obtained by adding the scores of all the items and then dividing by the number of items in that category. The higher the scores in that category, the more obvious the behavior the participant was in that dimension.

For the coach's version, Dwyer and Fischer (1988b) and Salminen and Liukkonen (1994) found that the Cronbach's alpha coefficients of the subscales, except 'Autocratic Behavior', ranged from .57 to .86 and from .71 to .85 , respectively. However, the alpha coefficients of 'Autocratic Behavior' were unacceptable (Dwyer \& Fischer, 1988b; Salminen \& Liukkonen, 1994). In spite of this, Salminen and Liukkonen (1994) concluded that the LSS is a valid instrument in leadership research, though the results of the 'Autocratic Behavior' should be interpreted with caution.

\section{Methods and Techniques}

The coach's self-perception version of the Leadership Scale for Sports (Chelladurai \& Saleh, 1980) was administered to basketball coaches in Hong Kong who voluntarily agreed to participate in the study. The coaches were those who participated in the Hong Kong Schools Sports Association (HKSSA) and the New Territories Schools Sports Association (NTSSA) InterSchool Basketball Boys A Grade Competition during the 1992-93 season. Females were excluded from the sample to control for a gender effect.

After the yearly competition was completed, a letter concerning the purpose and detail of the study and the participant consent form was sent to the participants. The basketball coaches were asked to sign and return the consent form within 2 weeks of receipt of the letter. The coach's self-perception version of the LSS and the demographic form were sent to the coaches after receiving their consent forms. The coaches were asked to return the questionnaire within 2 weeks of receipt of the letter. One week after the due date, follow-up phone calls and/ or reminder letters were sent to the coaches.

\section{Results}

A total of 56 high school male basketball head coaches served as the participants for this study. Twentyeight of the basketball coaches came from winning basketball teams while the other 28 basketball coaches came from losing basketball teams. The overall descriptive data for the subscales of the coach's selfperception version of the LSS of winning and losing basketball coaches are presented in Table 1. Winning coaches had higher mean scores than losing coaches in all subscales of the LSS except 'Positive Feedback Behavior' and 'Social Support Behavior'. However, the most common coaching behaviors for both the winning and losing coaches were, in descending order, 'Positive Feedback Behavior', 'Training and Instruction Behavior', 'Social Support Behavior', 'Democratic Behavior', and 'Autocratic Behavior'.
Table 1 : Descriptive Statistics of LSS Scores for Winning and Losing High School Basketball Coaches $(\mathrm{N}=\mathbf{5 6})$

\begin{tabular}{lllll}
\hline Variable & Mean SD & Min & Max & N \\
\hline
\end{tabular}

TRAINING AND

INSTRUCTION

$\begin{array}{llllll}\text { Winning } & 3.82 & .58 & 2.23 & 5.00 & 28 \\ \text { Losing } & 3.75 & .72 & 1.46 & 4.92 & 28\end{array}$

\section{DEMOCRATIC}

$\begin{array}{llllll}\text { Winning } & 3.12 & .53 & 2.22 & 4.33 & 28 \\ \text { Losing } & 3.11 & .45 & 2.22 & 3.89 & 28\end{array}$

\section{AUTOCRATIC}

$\begin{array}{llllll}\text { Winning } & 2.63 & .54 & 1.20 & 3.80 & 28 \\ \text { Losing } & 2.54 & .60 & 1.60 & 4.00 & 28\end{array}$

SOCIAL SUPPORT

$\begin{array}{llllll}\text { Winning } & 3.17 & .62 & 2.25 & 4.75 & 28 \\ \text { Losing } & 3.22 & .61 & 2.00 & 4.50 & 28\end{array}$

POSITIVE

FEEDBACK

$\begin{array}{llllll}\text { Winning } & 3.85 & .72 & 1.80 & 4.80 & 28 \\ \text { Losing } & 3.92 & .86 & 1.20 & 5.00 & 28\end{array}$


A one-way independent groups multivariate analysis of variance (MANOVA) was used to execute the multivariate analysis. The MANOVA program from the SPSS for Windows (Norusis, 1993) was utilized to compare the difference in the mean vector of scores on the following subscales between the winning and losing basketball coaches: (a) 'Training and Instruction Behavior', (b) 'Democratic Behavior', (c) 'Autocratic Behavior', (d) 'Social Support Behavior', and (e) 'Positive Feedback Behavior'. The Bartlett-Box test was computed to test the basic assumption of homogeneity of variance for each of the five subscales of LSS across the two independent groups. The Box M test was computed to test the homogeneity of the variance/covariance matrices for the scores from the winning and losing basketball coaches. The results of these analyses are presented in Table 2 .

Table 2: Bartlett-Box and Box M Tests for the Subscales of the Leadership Scale for Sports

\begin{tabular}{lcl}
\hline Subscale Name & Bartlett-Box F Value & $\mathrm{p}$ \\
\hline Training and Instruction & 1.23377 & .267 \\
Democratic & .67890 & .410 \\
Autocratic & .37846 & .539 \\
Social Support & .01156 & .914 \\
Positive Feedback & .80216 & .371 \\
\hline
\end{tabular}

Box $M=10.88289(p=.832)$

The Bartlett-Box M value for winning and losing coaches was non-significant ( $p>.05)$ which indicated that there were no significant differences in the variance/ covariance matrices for the two groups. The BartlettBox F ratios for the five subscales of the LSS were nonsignificant $(p>.05)$ indicating homogeneity of variance. The Wilks' tambda was used as a test for significant difference between the two vectors of means for the winning and losing coaches. No significant difference (Wilks' Lambda $=.967, \mathrm{~F}=.344$, df $=5,50, \mathrm{p}>.05$ ) was found between the winning and losing coaches with respect to the five subscale scores of the LSS. The results are shown in Table 3.

Table 3 : MANOVA Analysis Comparing LSS Subscale Scores of Winning and losing High School Basketball Coaches

\begin{tabular}{ccccc}
\hline Wilks' Lambda & Exact F & Hypo. df & Error df & $\mathrm{p}$ \\
\hline .967 & .344 & 5.000 & 50.000 & .884 \\
\hline
\end{tabular}

\section{Discussion}

The primary inquiry of the current study was to investigate the differences in leadership behaviors of winning and losing basketball coaches as determined by the Leadership Scale for Sports (LSS) (Chelladurai \& Saleh, 1980). From the responses of the basketball coaches in Hong Kong, no differences are expected between the coaching behaviors of the winning and losing coaches. This means that the coaches from both winning and losing basketball teams have similar leadership behaviors. The findings of this study are consistent with the findings of previous researchers (Callaway, 1983; Gabriel \& Brooks, 1986). Gabriel and Brooks (1986) indicated that there were no significant differences between the tennis coaches of the National Association of Intercollegiate Athletics (NAIA) and the National Junior College Athletic Association (NJCAA). They also found that the leadership behaviors of the LSS were not significant predictors of team win/loss percentage. In Hong Kong, an obvious factor that distinguishes winning and losing high school basketball teams is the skill level of the players. Leadership behavior, singly, may not be a predictor of winning and losing basketball coaching in Hong Kong.

Burns (1983) compared the perceptions of ideal leadership behaviors of Christian and non-Christian high school coaches and found that both coaches ranked autocratic behavior the lowest. Dwyer and Fischer (1988a) indicated that wrestling coaches were reported to have lower autocratic behavior. The findings of this present study are congruent with the results of the above studies, in which both winning and losing basketball coaches demonstrated 'autocratic' behavior to a lesser degree than the other behaviors as determined by the subscales of the LSS. One explanation for this result may be that in Boys A grade competitions, the athletes are mature and have about three or four years of experience. Therefore, 'autocratic behavior' may not be appropriate for those players.

Autocratic coaching behavior has been found in situations where the athletes were less mature and had lower skill levels (Robinson \& Carron, 1982); whereas at the highest level of maturity, a reduction in the task dimension is suggested (Chelladurai \& Carron, 1983). In Hong Kong, coaches appear to prefer close supervision of younger athletes (e.g., less than 14 years of age) or athletes with less experience, but not for mature athletes. A less autocratic coaching behavior may indicate that the 
coaches are attempting to establish a more equitable coach-athlete relationship. Moreover, discipline is emphasized by many of the school authorities in Hong Kong and the athletes typically will follow a coach's instructions. As a result, the coaches need not exert tight control over the behavior of their athletes.

Case (1987) studied the leadership behaviors of selected successful junior high, senior high, college, and Amateur Athletic Union head basketball coaches using the Leader Behavior Description Questionnaire (Halpin \& Winer, 1957). In his study, Case (1987) indicated that coaches demonstrated a high task and low relationship leadership behavior at the senior high and college levels. These findings were not consistent with those of the current study, in which the coaches attempted to set up a good relationship with the players, who were mostly senior high school students. Such discrepancy may be because of cultural differences of the coaches or the different expectations and ability levels of the players in these studies. Chelladurai, Imamura, Yamaguchi, Oinuma, and Miyauchi (1988) compared the preferred leadership of Japanese and Canadian physical education university students and found that the Japanese students in traditional sports preferred a more aloof and authoritarian leadership style than their counterparts. Therefore, both the cultural background of the students and the type of sports in which they are involved may affect the leadership preferences (Chelladurai et al., 1988).

The results of this study may have been influenced by the following factors. The LSS was designed primarily for use in sports in North America, thus it may not be applicable in Hong Kong where either the traditional sports or culture are different. Although, the coaches in North America emphasize winning and "do all they can to socialize their athletes with the value of winning" (Eitzen \& Sage, 1989, p. 66). The situation is different in Hong Kong where a greater emphasis is placed upon the academic performance of individuals. Inter-school competitions may be regarded as extra-curricular activities. Because winning is not highly valued by the participants, this study may not have revealed the actual leadership behaviors of some of the coaches.

There may be some other factors which may also have affected the reliability of this study. For example, the English version of the LSS may not be appropriate for the participants in Hong Kong, where over $90 \%$ of the population use Chinese as their primary language.
Moreover, some of the items of the LSS may not be clear enough for the participants (Zhang, 1993). Therefore, use of a Chinese version of the LSS with improvement in the wordings of some of the items (e.g., those items under 'Autocratic Behavior') may present different results. Furthermore, the ability level of the players will also affect the win/loss record of the competition. As a result, the leadership behavior of the coaches is not the only factor that determines the team results. In this situation, the skill level and performance of the players may have had a decisive role in determining whether the team on which the players participated was either a 'winning team' or 'losing team'.

Since only the coach's self-perception version of the LSS was used in this study, the results were confined to the subjective ratings of the coaches themselves, whereas the actual leadership behaviors of the coaches were not determined objectively. Coaches may choose more autocratic styles than the players (Chelladurai, Haggerty, $\&$ Baxter, 1989) and athletes may perceive the coaching behaviors more negatively than do the coaches themselves (Kenow \& Williams, 1992). In order to have a better idea about coaching behaviors, perhaps the athletes' perceptions of the behaviors of their coaches should be assessed through the other versions of the LSS (i.e., the athlete's preference and the athlete's perception of coach's behavior versions) so that preferred and perceived leader behaviors of the athletes can be compared with the coaches' perception of their own behaviors. Future studies should also examine cultural influences on coaching behaviors with respect to other contingent variables.

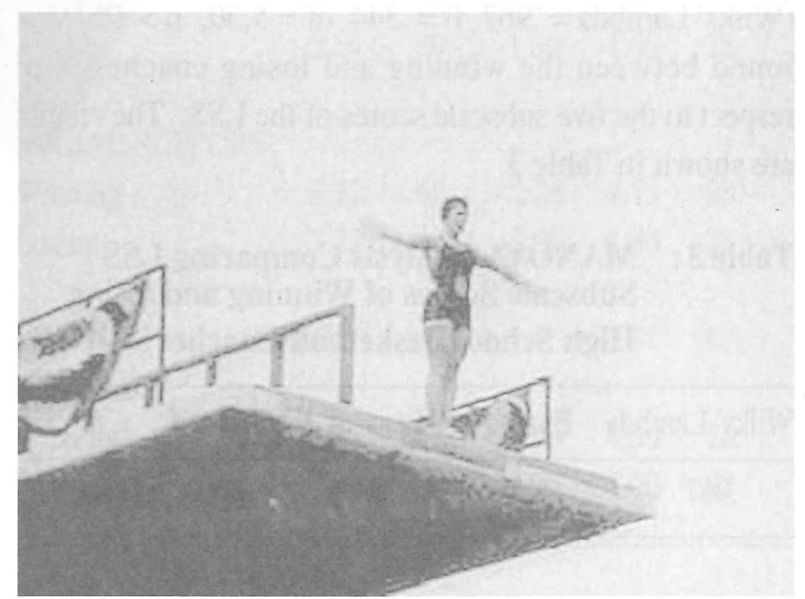




\section{References}

Burns, C. A. (1983). Perceptions of ideal leadership behavior: Christian versus non-Christian women high school coaches. Ann Arbor, MI: University Microfilms.

Callaway, D. J. (1983). A comparison of leadership styles of successful and unsuccessful collegiate women basketball coaches. Ann Arbor, M I : University Microfilms.

Case, B. (1987). Leadership behavior in sport: A field test of the Situational Leadership Theory. International Journal of Sport Psychology, 18(4), 256-268.

Chelladurai, P. (1985). Sport management: Marco perspectives. Ontario, Canada: Sports Dynamics.

Chelladurai, P., \& Carron, A. V. (1983). Athletic maturity and preferred leadership. Journal of Sport Psychology, 5, 371-380.

Chelladurai, P., Haggerty, T. R., \& Baxter, P. R. (1989). Decision style choices of university basketball coaches and players. Journal of Sport and Exercise Psychology, 11(2), 201-215.

Chelladurai, P., Imamura, H., Yamaguchi, Y., Oinuma,Y., \& Miyauchi, T. (1988). Sport leadership in a cross-national setting: The case of Japanese and Canadian university athletes. Journal of Sport and Exercise Psychology, 10(4), 374-389.

Chelladurai, P., \& Saleh, S. D. (1980). Dimensions of leader behavior in sports: Development of a leadership scale. Journal of Sport Psychology, 2, 34-45.

Dwyer, J. J., \& Fischer, D. G. (1988a). Leadership styles of wresting coaches. Perceptual and Motor Skills, 67(3), 706.

Dwyer, J. J., \& Fischer, D. G. (1988b). Psychometric properties of the coach's version of Leadership Scale for Sports.Perceptual andMotor Skills, 67(3), 795-798.

Eitzen, D. S., \& Sage, G. H. (1989). Sociology of North American sport (4th ed.). Dubuque, IA: Wm. C. Brown.

Gabriel, L., \& Brooks, D. (1986, October-November). An investigation of the leadership behavior of selected NAIA and NJCAA women's tennis coaches. Paper presented at the meeting of North American Society for the Sociology of Sport, Las Vegas, NV.
Halpin, A. W., \& Winer, B. J. (1957). A factorial study of the leader behavior descriptions. In R. M. Stogdill \& A. E. Coons (Eds.), Leaderbehavior: Its description and 0 measurement (pp. 39-51). Columbus, OH: Ohio State University.

Kenow, L, J., \& Williams, J. M. (1992). Relationship between anxiety, self-confidence, and evaluation of coaching behaviors. Sport Psychologist, 6(4), 344- 357.

Norusis, M. J. (1993). SPSS for Windows: Base systemuser's guide, release 6.0. Chicago, IL: SPSS.

Robinson, T., \& Carron, A. (1982). Personal and situational factors associated with dropping out versus maintaining participation in competitive sport. Journal of Sport Psychology, 4, 364-378.

Salminen, S., \& Liukkonen, J. (1994). The convergent and discriminant validity of the coach's version of the Leadership Scale for Sports. International Journal of Sport Psychology, 25(1), 119-127.

Zhang, J. (1993). Modification and revision of the Leadership Scale for Sports. Unpublished doctoral dissertation, Springfield College, Springfield, MA.

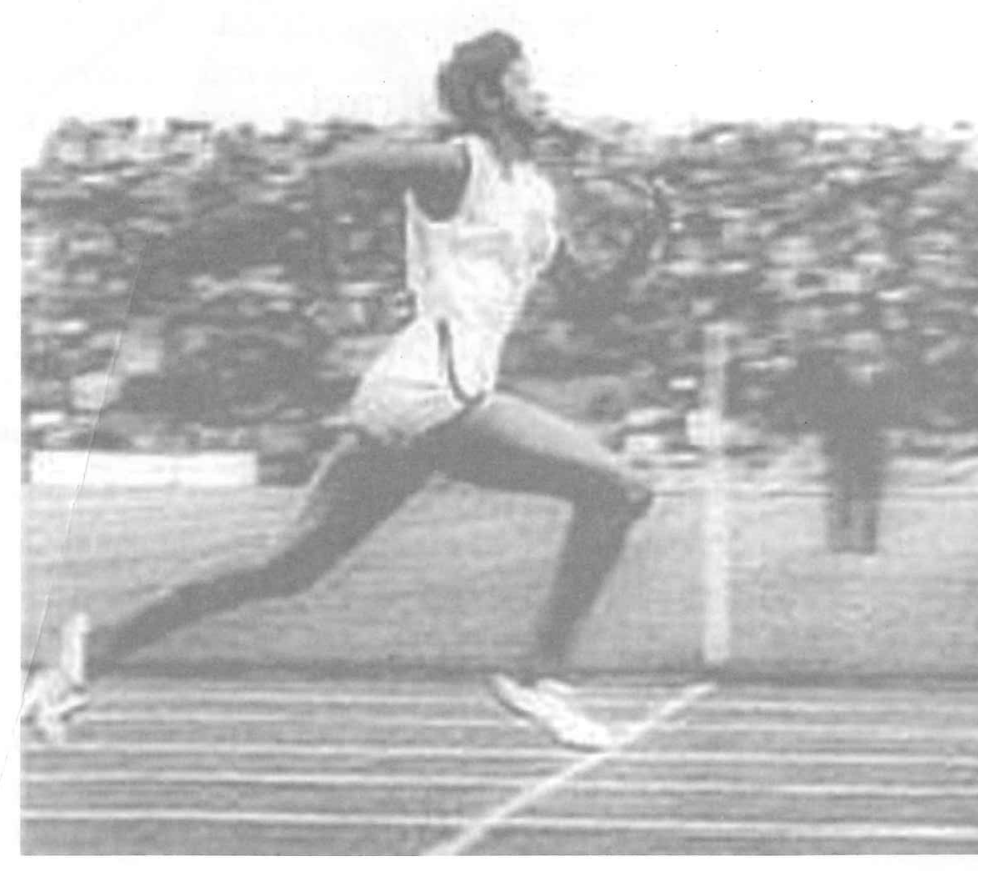

